\title{
Epidemiology and the legal basis for corneal transplants in Poland
}

\author{
Rafał Patryn ${ }^{1}$, Andrzej Grzybowski², ${ }^{2}$, Jarosław Sak , Beata Rymgayłlo-Jankowska ${ }^{4}$ Anna Zagaja ${ }^{1}$ \\ 'Department of Ethics and Human Philosophy, Medical University of Lublin, Lublin, Poland \\ ${ }^{2}$ Department of Ophthalmology, Poznan City Hospital, Poznan, Poland \\ ${ }^{3}$ Department of Ophthalmology, University of Warmia and Mazury, Olsztyn, Poland \\ ${ }^{4}$ Department of Diagnostic and Microsurgery of Glaucoma of the Medical University of Lublin, Lublin, Poland
}

\begin{abstract}
The article aims at presenting a legal basis for corneal transplantation - the most frequently conducted transplantation procedure in Poland. Applicable rules and regulations concerning transplantation can be found in the Cell, Tissue, and Organ Recovery, Storage, and Transplantation Act of July 1, 2005 and the Regulation of the Minister of Health of December 4, 2009 on detailed conditions of removal, preservation, and transplantation of cells, tissues, and organs. However, the scope and content of the above legislation does not directly refer to corneal transplantation, neither in concept nor description, which may lead to certain misinterpretations and ambiguity of information as to the adopted rules of corneal removal, transplantation and the existing formal solutions (documentation, or rules for obtaining consent). The article refers to a very important legal principle - omnia sunt interpretanda - which in practice obliges the description and proper interpretation of the legal rules pertaining in this content to such procedures. In terms of legalisation it is possible to find only norms concerning the possibility of obtaining and transplanting corneas, entities which can conduct such procedures (after obtaining the consent of the Ministry of Health), and information on the scope of the so-called presumed consent that is one of the basic legal mechanisms allowing tissue procurement from deceased donors. The summary is a synthetic and comprehensive presentation of current knowledge and the legal situation of corneal transplantation, which can prove useful in an appropriate interpretation of legal standards regarding such procedures.
\end{abstract}

KEY WORDS: graft, cornea, legislation, ocular tissue

Ophthalmol J 2016; Vol. 1, No. 4, 137-146

\section{INTRODUCTION}

According to statistics from 2014, there were 2055 organ transplants conducted in Poland altogether (1120 kidney, 336 liver, 76 heart, and 19 lung transplants) [1]. In December 2014, there were 2638 registered recipients waiting for a corneal transplant [2], and there were 939 and 884 corneal transplants in 2014 and 2015, respectively [1]. In Poland, the number of people with visual impairment exceeds 500,000. Data indicate that nearly $1 \%$ of the world's population has serious vision impairments, and the total number of blind and partially sighted is still growing [3]. Many people suffer from corneal damage, which at the current state of medical knowledge and technology can be treated through transplantation. Corneal transplantation does not require the donor to be immunologically compatible with the recipient; however, the success of the transplant depends on the quality of the donor's cornea prior to surgery, the quality of the donor's tissue, and the equipment used. The cornea is usually taken in the form 
of a corneal-scleral flap and is placed in a special preservative fluid, which allows for safe storage and transport of the collected tissue [4]. A corneal transplant can be partial or full thickness [5], and the graft is taken from a deceased donor [4]. The tissue from adult donors must be collected within 12-18 hours after death. The corneas from infants and children under three years old are taken extremely rarely due to surgical and refractive problems as well as high probability of transplant rejection. Corneas after procurement but before transplantation are stored in the Eye Tissue Bank (BTO, Bank Tkanek Oka), where the assessment of tissue suitability of the graft, including molecular and serological testing of the donor's blood, is carried out in order to rule out factors that would disqualify the deceased as a potential donor. The medical history interview conducted for this purpose initiates the procedure of obtaining corneas for transplant and includes: verifying the existence or the lack of an objection in the Central Register of Objections (CRS, Centralny Rejestr Sprzeciwów), checking for any other forms of objections, an analysis of the donor's medical records, an interview with a person who can provide detailed information about the donor (in case of a deceased donor), and an interview with the doctor who treated the donor (including an interview with a primary care physician). The results of a biopsy of the potential donor are thoroughly analysed with the ultimate cause of death. In this case, the medical interview pertains to the analysis of the following [6]:

- report of post-mortem examination (autopsy results are available approximately one to two days after tissue procurement);

- results of physical examination (body inspection) of the deceased in order to detect any conditions that would rule him/her out as a donor;

- medical records concerning the evaluation of medical state of the donor for the suitability of the collected tissue [7];

- other criteria that would exclude the potential donor's tissues or cells on the basis of detailed information [8].

The study of the donor's blood includes serological and molecular tests for the presence of HIV 1 and 2, anti HIV 1 and 2, hepatitis B HBsAg and anti-HBc, and hepatitis C: anti HCV and serological tests for syphilis. It is also necessary to perform the following tests [8]:

- test for HTLV-1 antibodies among donors living in areas with high morbidity or who come from such areas or whose sexual partners or parents originate from such areas;

- in case of a positive anti-HBc test and a negative HBsAg test it is necessary to evaluate further risks, determining the suitability of the procured tissue for clinical use;

- depending on the data found in the donor's medical records and the characteristics of the procured cells or tissues, the donor should undergo additional tests such as for the $\mathrm{RhD}$ and HLA antigen towards malaria, CMV, toxoplasmosis EBV, and the Trypanosoma cruzi protozoa.

Standard surgical procedures associated with cell or tissue retrieval are also determined: the manner in which the above are collected and transferred to the receiving entity, equipment used for transplants, specialist packaging, marking, method of identification, etc. [8]. Harvested corneas undergo microscopic examination, including the density of endothelial cells. Donor's corneas are stored in a temperature above $4^{\circ} \mathrm{C}$ for up to 14 days or in tissue cultures (even up to six weeks) [8].

\section{CURRENT LEGAL SITUATION — ANALYSIS}

In interpreting the current legal status, i.e. provisions related to the possibility of transplantation of the cornea, it should be noted that the very concept of the cornea does not occur as a direct medium with defined and assigned legal norms or standards. In this case, for the legal analysis it is necessary to apply a definition that will expand its designation. The review and analysis of European and national legislation conducted in the further parts of the article will allow for the presentation of the most important issues concerning corneal donation, rules for its storage, and the accompanying formal-legal solutions. Simultaneously, in connection with the adoption of the interpretation of the cornea, as human tissue, wherever the word "tissue" is used (directly or in the context) by extension of concepts it will be identified with the cornea.

\section{EUROPEAN REGULATIONS}

The most important Act of European priority is Directive 2004/23/EC of the European Parliament and of the Council of 31 March 2004 on setting standards of quality and safety for the donation, 
procurement, testing, processing, preservation, storage, and distribution of human tissues and cells. This Directive, on a community level, determines and legalises transplants, provides basic rules of recipient security, protects sensitive data of both donors and recipients, and delivers basic principles related to the functioning of tissue banks. In the broad scope, the Directive concerns tissues and cells, including haemopoietic stem cell, umbilical cord blood, bone marrow stem cells, reproductive cells (oocytes, sperm), foetal tissues and cells, and adult and embryonic stem cells [9]. This Act states and provides legal basis for transplantations, determining that the tissues and cells used for allogeneic therapy can be collected from living as well as dead donors, and provides the requirement of medical examination prior to intervention. The next essential principle of this act specifies that, because it is crucial to respect the dignity of the dead donor, after material harvesting it is necessary to reconstruct the body so that it is as close as possible to its original anatomical shape. In the Directive, tissues are defined as all the components of the human body formed by cells, and the donor is defined by any type of living or dead source of human tissues and cells. Tissue banks are facilities that conduct activities related to the processing, preservation, storage, and distribution of human tissues and cells, and they can also be responsible for the procurement of tissues. The Directive pays much attention to the obligation of data protection and security, mainly the protection of donor's data and the protection of other data obtained during transplantation. It postulates the introduction of security measures against unauthorised disclosure, removal, or any modifications in the medical documentation [9].

Another important act is the Commission Directive 2006/17/EC of 8 February 2006 implementing Directive 2004/23/EC of the European Parliament and of the Council as regards certain technical requirements for the donation, procurement, and testing of human tissues and cells. This Directive in turn, concerns mainly medical issues associated with limiting the risk of disease transfer or other potential threats to the recipient [10]. This risk is decreased through the introduction of careful donor selection and analysing tissue procurement procedures and their consistency with the principles and processes of realising the idea based on the best available scientific knowledge. Additional protection is provided by the introduction of the so-called standards of surgical procedures based on the verification of the following information: the donor's identity, donor's consent or family authorisation, evaluation of the criteria for donor selection, and the evaluation of laboratory tests required for individual donors. Basic criteria for donor selection are based on the analysis of risks associated with the use of harvested tissue. Their rates are determined through physical examination, the analysis of medical history, community interview, biological research and post-mortem examination (in cases of deceased donors). General exclusion criteria for deceased donors include [10]:

- unknown and unspecified cause of death;

- disease of unknown aetiology;

- cancer except for primary basal cell carcinoma, carcinoma in situ of the cervix, and some primary tumours of the central nervous system that have to be assessed according to current scientific knowledge;

- the risk of transmission of diseases caused by prions (e.g. people diagnosed with CreutzfeldtJakob disease);

- systemic infection that is not controlled at the time of donation (bacterial, viral, fungal, or parasitic infection in the tissues and cells that are to be harvested);

- a history, or clinical or laboratory evidence of HIV infection, acute or chronic hepatitis B (except for those with a proven immune status), hepatitis C, and HTLV I/II;

- chronic, systemic autoimmune disease that could have a detrimental effect on the quality of the tissue to be harvested;

- invalid results of donor blood samples (occurrence of haemodilution, treatment with immunosuppressive agents);

- evidence of other risk factors associated with infectious diseases;

- presence of physical signs on the donor's body implying a risk of infectious disease (diseases) as described in Annex IV, point 1.2.3;

- intake of, or exposure to, substances such as cyanide, lead, mercury, gold;

- vaccination with a live attenuated virus, in an interview, if there is a risk of transmission;

- the use of xenografts.

What needs emphasis is the fact that donors with malignant diseases may be evaluated and considered for cornea donation, except for those with retinoblastoma, haematological neoplasm, and malignant tumours of the anterior segment of the eye- 
ball. Also, donors with bacterial septicaemia may be evaluated and considered for eye donation but only where the corneas are to be stored in organ culture to detect any bacterial contamination of the collected tissue [10].

\section{NATIONAL REGULATIONS}

The Act of 1 July 2005 on the collection, storage, and transplantation of cells, tissues, and organs defines the rules for the collection, storage, and transplantation of cells, including haematopoietic cells of the bone marrow, peripheral blood and umbilical cord blood, tissues, and organs derived from a living donor or a cadaver [7]. The Act determines the source of the tissue as the living or dead donor from whom the cells, tissues, and organs are to be collected. The tissue is defined as a set of cells with specialised functions connected with each other by an intercellular substance. The Tissue Bank (Eye Tissue Bank) is defined as an organisational unit responsible for the collection, processing, sterilisation, storage, and distribution of tissues and cells. The Act allows and suggests the possibility of collecting cells, tissues, or organs from cadavers, which is basic for cornea harvesting. It should be stressed that this Act establishes a legal classification of the possibility of harvesting, or in the colloquial sense, depriving cadavers of anatomical parts in special situations (the harvested "part" will be used to save lives or improve the quality of health of another human being). Cells, tissues, or organs can be taken from human corpses for diagnostic, therapeutic, research, and teaching purposes. What is very important - in the absence of a legal basis, ridding the body of any integral part would be a form of profanation (and even a specific form of theft) associated with the desecration and lack of reverence for the dead, which naturally would be punishable by law. Therefore, this Act legalises the process of transplantation. This document also sets out a very important element associated with formal legality of organ donation; namely, it introduces the concept of the so-called presumed consent [7].

The principle of presumed consent implies that anyone who during his/her lifetime did not object in an established manner to organ and tissue donation agrees to donate his/her organs after death. From the perspective of legal norms, it is an agreement for something (removal of tissue) that will take place in an unspecified future (after death), i.e. without the awareness of self-determination (determination as to one's own body or its components). The adopted principle relies on an idealistic assumption that every person "agrees" to donate their organs and tissues after death, so that those organs/tissues can save lives and restore health of others. However, an opposite situation may occur where there is no consent for organ/tissue donation after death. In such a case, it is possible to express objection, which will be in force after death. Any objection, expressed in a previously established way, will not allow doctors (after verification of its possible forms) to continue with organ/tissue transplantation. The construction of presumed consent has rational and practical reasons and motivations. It rationally assumes that with the individual's death "organs/tissues are no longer needed" and those organs/tissues may function in a different body. In a practical dimension the doctor intending to harvest organs or tissues checks whether there is no objection in the CRS (Central Register of Objection) (www. poltransplant.org.pl/form_main.html). If there is no record of any objection in the CRS held by Poltransplant, or there is no appropriate statement (written or oral filed earlier in the presence of witnesses and confirmed by them in writing) the process of organ/tissue harvesting and storing can begin (cornea). It should be underlined that the law allows for the creation of a document (written declaration), which will clearly and explicitly inform that the person who signed it does not allow the use (harvesting) of his/her organs in case of death (including brain death) for the purpose of transplantation. In real life situations such a statement may cause certain difficulties: first of all these statements should be carried with the potential donor constantly and the finding and verification of such documents by the medical staff is time consuming and may postpone procurement. Additionally, it raises further issues related to e.g. where such a document should be kept. As to the mentioned oral statement of objection, the Act determines that the collection of cells, tissues, or organs from cadavers for their further transplantation can be done if the deceased person did not express an oral objection (lack of consent for organ donation) in the presence of two witnesses and confirmed by them in the form of a signature. This is specified by article 6, paragraph 1 of the Act of 1 July 2005 on the collection, storage, and transplantation of cells, tissues, and organs. The provisions 
of paragraph 1 are also applied to the objection expressed by the legal representative. The established forms of objection such as personally signed statement and an oral statement made in the presence of at least two witnesses in the practice constitutes and essential problem for facilities storing corneas (tissue banks) [7]. The problem is to determine, apart from when the objection was made in the Central Objection Registry, whether there were any other forms of objections as found in point 2 and 3 (point 2 requires a written statement of objection for organ harvesting, but the practice and reality, or the necessity of searching for such a statement shows that the implementation of this structure is problematic). Additionally (point 3), when the donor's family questions the circumstances of organ harvesting and summons the donor's oral objection as to the donation of organs, cornea in this case, it is also problematic. The problem of the interpretation of presumed consent requires a broader analysis that exceeds the subject of this study. The above-mentioned Central Registry of Objection for harvesting cells, tissues, and organs is kept by the Organisation-Coordination Centre - "Poltransplant" [7], and in order to place an objection the person who wishes to do so needs to provide the following information [7]:

- name and surname;

- date and place of birth;

- social security number, if there is one (this data is stored for a period of five years from the date of death of the person objecting, and after expiry of that time they are destroyed to prevent identification);

- address and place of residence (data stored for a period of five years from the date of death of the person objecting, and after expiry of that time they are destroyed to prevent identification);

- date when, and place in which, the objection was made or withdrawn;

- the date of obtaining the notification of objection.

Information from the Central Register of Objections shall be provided immediately after receiving questions from the physician intending to harvest organs or a person authorised by him/her (www.poltransplant.org.pl/pozwolenia.html). An extremely important aspect is the criteria of brain death because these criteria and the overall definition of brain death determined by the transplantation act has evolved over time. The transplantation act prior to amendments (before 2009) states that death occurs with the permanent, irreversible cessation of the brain stem, the so-called death of the brain stem. The new law defines the death of an individual by the death of the individual's whole brain, i.e. permanent and irreversible cessation of brain functions (the definition has been broadened from brain stem to the whole brain with the introduction of the circulatory criteria - article 9a) [7]. According to the majority of medical stances, the death of the brain is equivalent to the death of an individual. The cornea is harvested from cadavers, and the "type of death" is irrelevant, i.e. whether it occurred naturally, was an outcome of an accident, outcome of a disease, or whether brain death was declared. The Act also introduces another important legal principle: professional confidentiality. Personal data of the potential recipient are confidential and protected under the provisions of professional confidentiality, provisions on medical records kept by medical entities, and provisions on personal data protection [11-13]. According to regulations, storage of corneas in tissue and cell banks is possible after the facility obtains permission from the Ministry of Health to conduct such procedures. This permission is granted for a period of five years by the Minister of Health at the request of the National Centre for Tissue and Cell Banking, after an opinion issued by the National Council of Transplantation. The cell and tissue bank obtains such permission if it meets the following requirements [7]:

- it employs qualified personnel, including the person responsible for compliance with the legal regulations and rules determined in the quality assurance system;

- it has facilities and equipment meeting professional and sanitary requirements;

- it presents a draft of a quality assurance system (establishing in detail the methods of monitoring cells and tissues, surveillance of transfer conditions between donor and recipient, and the quality of all medical devices and materials, which have direct contact with those cells and tissues).

The application for permission should be accompanied by information on the number of employees, their qualifications, the opinion of the local health inspector on the fulfilment of the requirements found in the regulations, list of rooms and facilities, organisational structure of the bank, responsibilities of bank employees, and the pos- 
sibility to foresee the scope of activities and the list of entities with which the bank will collaborate based on a written agreement. Cell and tissue banks are required to collect and keep medical records on the stored and issued cells and tissues for at least 30 years from their date of issue for transplantation, in a manner that will allow identification of both donors and recipients. The documentation can also be stored in electronic form. It is necessary to note that the storage time for medical documentation in the bank is established for 30 years, which is longer than the usual requirement of storing medical documentation, i.e. 20 years (with exceptions) [14]. The above-mentioned permit of the Minister of Health to store the corneas in the tissue and cell banks has a very wide range and may include:

- transplantation of corneas from deceased donors;

- harvesting the corneal limbus from a living donor and its auto- and allogeneic transplantation;

- transplantation of the cornea and corneal limbus from deceased donors;

- amniotic membrane transplantation;

- transplantation of the cornea and sclera fragments from a deceased donor.

The executive Act to the mentioned law is the Minister of Health regulation of 4 December 2009 concerning detailed conditions of harvesting, storage, and transplantation of cells, tissues, and organs [15]. The Regulation defines professional qualifications of people (including coordinators) receiving cells, tissues, and organs, as well as the people who conduct transplantations. The Regulation also indicates conditions that should be met by entities responsible for storing of the harvested tissues, cells, and organs, the requirements as to the medicinal entities performing transplants, and the requirements to be met by medical documentation concerning the collection, storage, and transplantation of cells, tissues, and organs. The most important rule in the regulation states that the only ones allowed to retrieve cells and tissues from human corpses are doctors and procurement teams. Cells and tissues from cadavers can be taken for transplantation in health care facilities (in medical entities, according to the new terminology) with an operating or autopsy room, forensic medicine centres, pathological anatomy departments of universities with medical divisions, and research facilities with an autopsy theatre. Medical documentation on the collection of cells, tissues, and organs, and their storage and transplantation include:

- a donor card containing the following elements: identity of the donor, i.e. name and surname. If there is a mother and a child included in the donation, then also the full name of the child; date of birth; social security number (if assigned); age; sex; medical history (if available); community interview (if it is possible to carry one out); the result of a physical examination; type of applied haemodilution; the result of clinical or post-mortem examination and, in the case of cells or tissues that cannot be stored for long periods of time, the verbal result of a preliminary autopsy; results of laboratory tests and other studies [6];

- recipient card specifying: recipient's identity (full name); date of birth; social security number; age; gender and description of the transplantation of cells, tissues, or organs;

- reports concerning serious adverse events and serious adverse reactions and steps taken to resolve them and prevent them in the future [15];

- documentation of inspection in the case of the above events, including inspection records and a list of measures taken to eliminate irregularities;

- records of collected, stored, and transplanted cells, tissues, and organs, containing data about the potential or real donor, a potential or real recipient, the place and time of procurement, data about the doctor responsible or a person authorised by him/her for the organ/tissue retrieval, the results of all performed tests, data on the preparation and storage, unique ways of marking (ISBT 128), and confirmation of issuing of cells, tissues, or organs to the physician responsible for the transplant. ISBT 128 standard relates to methods for identification, labelling of blood and blood components, as well as of human tissues and organs [16].

The above documentation can also be created, stored, and made available in an electronic version. The main medical indications for corneal transplant include the absence of the optical function in the current cornea, the development of a specific disease that contributed to the destruction of the cornea and intractable inflammation. Specifically, they pertain to the following diseases [17]:

- keratoconus;

- corneal ecstasy;

- anterior corneal dystrophy;

- stromal corneal dystrophy; 
- Fuchs' dystrophy;

- other corneal dystrophies;

- traumatic scars;

- other scars on the cornea;

- bullous keratopathy;

- other degenerative states of the cornea;

- keratitis;

- endosperm;

- other corneal opacities;

- corneal ulceration;

- corneal malacia;

- threatening perforation of the cornea;

- corneal perforation;

- congenital abnormality of the cornea;

- decompensation of the transplanted cornea flap;

- other disease of the cornea.

The terms of qualifying the patient for cornea transplantation are determined in the National Waiting List. In turn, the allocation rules are closely related to the classification of patients for the transplant and their position on the waiting list. The allocation can be done in two modes: urgent or scheduled. Patient selection is carried out in medical entities dealing with corneal transplants, which have obtained prior permission from the Minister of Health. The first condition of receiving a transplant is to be enrolled on the active waiting list (www.rejestry.net). The list has nationwide coverage and is the only form of confirmation that a patient is waiting for a cornea, along with information on the urgency of the transplantation [17]. The date of being enrolled on the waiting list is the time from which the waiting period begins. As mentioned above, there are two modes of indication for transplantation: urgent and scheduled. The urgent mode requires that at least one of the following criteria is fulfilled [17]:

- corneal disease occurring in patients under 18 years of age;

- perforation of the cornea or hernial protrusion of Descemet's membrane;

- acute inflammation of the cornea with necrosis;

- corneal oedema which may result in fibrotic stroma among patients eligible for endothelial keratoplasty;

- corneal disorders giving corrected visual acuity of 0.1 or less in the better eye or only in one eye. The urgent mode requires the updates of recipient data every seven days. Criteria for selecting the recipient (order criteria) are as follows [17]:

- first, priority is given to recipients under 18 years of age. If there is more than one person fulfilling this criterion, the first to get the transplant is the person who has been waiting the longest. The distribution of the corneas from the tissue bank has in these cases both local and national scope;

- second, priority is given to patients from the urgent mode from indications provided in subparagraphs b, c, d, and e. From this list, priority is given to those who have been waiting for the transplant the longest. The distribution of the corneas from the tissue bank has in these cases both local and national scope;

- in the third place, the transplants are offered to patients who were scheduled for the procedure. From this list, priority is given to those who are waiting the longest. The distribution of the corneas from the tissue bank has in these cases both local and regional scope.

The distribution of corneas by eye banks is guided by three principles:

- distribution on a national scale: the cornea is sent to the recipient enrolled on the waiting list, to any centre in the country;

- regional distribution: the grafted cornea is sent to the recipient who is within the bank's region [17];

- local distribution: the cornea is given to the recipient from the centre that harvested the cornea (only one of the collected pairs of corneas can be distributed locally).

After sending the corneas, the centre that deals with transplantations and Poltransplant draws up a protocol of allocation and distribution [17]. The bank can provide two corneas to the transplantation centre, just in case there is a need to use both (safety transplant). If the second cornea is to be used for a different recipient, the centre choses a recipient based on medical criteria and waiting time according to the table from the Poltransplant webpage (among recipients qualified for corneal transplant within the centre). The centre, which obtained two layered grafts from one cornea, choses a second recipient based on the above-mentioned criteria and according to the table of sequence on the Poltransplant webpage and among recipients qualified for transplantation within that centre. After transplantation, the centre makes an entry in the transplant registry and sends a protocol on choosing a particular recipient to both Poltransplant and the Tissue Bank.

\section{THE CURRENT SITUATION RELATING TO CORNEAL TRANSPLANTS}

According to available national data, the number of corneal transplants performed in the years be- 
Table 1. Number of corneal transplants (n) in Poland between 2010 and 2016

\begin{tabular}{|l|c|c|c|c|c|c|c|}
\hline Year & 2010 & 2011 & 2012 & 2013 & 2014 & 2015 & 2016 (until August) \\
\hline $\mathbf{n}$ & 623 & 905 & 855 & 833 & 939 & 884 & 444 \\
\hline
\end{tabular}

Table 2. Data concerning tissues and eyeballs in the years between 2008 and 2015 harvested by the Eye Tissue Bank in Poland

\begin{tabular}{|l|c|c|c|c|c|c|c|c|}
\hline Year & 2008 & 2009 & 2010 & 2011 & 2012 & 2013 & 2014 \\
\hline A & 605 & 771 & 716 & 1294 & 1102 & 1140 & 1219 \\
\hline Year & 2008 & 2009 & 2010 & 2011 & 2012 & 2013 & 2014 \\
\hline B & 187 & 256 & 228 & 214 & 145 & 154 \\
\hline
\end{tabular}

A - summary of the corneal-scleral rings harvested by the Eye Tissue Bank in the years between 2008 and 2015; B - summary of the eyeballs harvested by the Eye Tissue Bank in the years between 2008 and 2014

Table 3. Data concerning harvesting of eye tissue and the distribution of corneas in the years between 2010-2015

\begin{tabular}{|l|c|c|c|c|}
\hline Year & $\begin{array}{c}\text { Number of donors of eye } \\
\text { tissues }\end{array}$ & $\begin{array}{c}\text { Number of harvested eye } \\
\text { tissues }\end{array}$ & $\begin{array}{c}\text { Number of transplants of } \\
\text { corneas authorised for } \\
\text { distribution }\end{array}$ & $\begin{array}{c}\text { Number of corneas dis- } \\
\text { tributed among hospitals }\end{array}$ \\
\hline 2010 & 480 & 716 & 816 & 623 \\
\hline 2011 & 652 & 1294 & 1177 & 905 \\
\hline 2012 & 559 & 1104 & 870 & 855 \\
\hline 2013 & 579 & 1140 & 897 & 833 \\
\hline 2014 & 614 & 1219 & 964 & 939 \\
\hline 2015 & 533 & 1057 & 844 & 821 \\
\hline
\end{tabular}

tween 2007 and 2013 in Poland was 5641 procurements and 4961 transplants. In 2014 and 2015 it was 1823 transplants and in 2016 (until august) it was 444 [18, 19]. Data on: conducted transplants, harvesting of eye tissue, and distribution of corneal transplants in 2010-2016 are shown in Table 1. A summary of the corneal-scleral rings and eyeball tissues harvested by the Eye Tissue Bank in the years between 2008 and 2015 are shown in Table 2.

\section{END NOTES}

The presented legal solutions are to normalise and determine in a functional and rational way this innovative field of medicine, i.e. transplantation. With the possibility of corneal transplantation, legal norms, which in their scope are to pertain to this specialist medical procedure, had to be established. Therefore, the assumption of readability in reception, both for recipients and for persons engaged in this type of treatment, i.e. doctors, must be fully guaranteed. In the described legal acts, a great deal of emphasis is placed on the donor's medical tests so that the tissue is safe for transplant, on the rules relating to the storage of the procured tissue, and the simplicity of the transplantation process. The rules also regulate the issues of protection and the safety of transplantation procedures, including confidentiality, and the rules pertaining to keeping and protecting patients' medical records. The process associated with the collection and storage of corneas in the eye tissue banks was limited by legislature to a formal method of obtaining the Minister of Health's consent for such activities. The corneal donation usually comes down to the procurement of this tissue from the cadaver (permission for transplantation of corneas needs to be granted by the Ministry of Health). Therefore, in such a case there is a necessity to remember the applicable principles of respect for the deceased, which are also enumerated and marked in the regulations. Another issue to be addressed is presumed consent, which in practice may and does cause interpretational problems (and usually manifests itself as the family's objection). Lack of objection in the Central Registry of Objections allows the doctor to initiate the procurement process; however, other possible and difficult-to-verify forms of objection can hinder and 
block the process. It seems that the scope of the presumed consent in its practical interpretation is highly limited by the occurrence of situations referred to in Article 6, Paragraph 1, Point 2 and 3 of the Cell, Tissue, and Organ Recovery, Storage, and Transplantation Act of July 1, 2005. Therefore, it is a possible foundation for discussion of the development of a different type of consent (an alternative, family consent), which would clarify the family's instruction as to obtaining the corneal tissue.

Full commercialisation, i.e. paid corneal transplants, is not allowed in Poland. It is an illegal activity defined by articles 43 to $46 \mathrm{~b}$ of the cited Act. There, according to article 44, whoever, in order to obtain material or personal benefit, acquires and disposes of someone's tissue, mediates in the purchase or sale of, or is involved in transplantation or provides tissues obtained against the provisions of the Act from a living or dead donor, may be imprisoned from six months to five years. The whole process, from the moment of procurement (of the qualified corneas) through its storage, issuing, and transplantation, is described and formally defined. After the procurement, a cornea must be transferred to one of the seven eye tissue banks. In the tissue bank, the corneas undergo extensive and multi-faceted tests, the results of which make them eligible for transplantation. The doctor responsible for transplantation needs to order from the eye tissue bank a cornea suitable for his/her patient, who is on the waiting list and meets relevant medical criteria [7]. The procedure is entirely funded by the National Health Fund within the framework of individual tenders and contracts. It should be noted that the funds for financing corneal transplant (until June 2009) came from two sources: the Ministry of Health (highly specialised services) and the National Health Fund. Since 2009, the procedure (excluding keratectomy) is not financed by the Ministry of Health but from the National Health Fund in the context of services in the field of "hospital treatment" [20]. In 2013, the Ministry of Health announced a contest for the years 2011 to 2020 under the title "National Program for the Development of Transplantation Medicine" in the scope concerning corneal transplants among patients at risk of graft loss from immunological causes, which may suggest the return to the financing or co-financing of the corneal transplants by the Ministry of Health. The conclusion of the analysis is the statement that the law that governs this medical treatment must be very precise in its dimension and must be subjected to a specific evolution in response to the widespread expectations for this form of assistance to patients in need.

\section{ACKNOWLEDGEMENTS}

The authors would like to thank the following individuals and institutions for providing detailed and required data to the article: Prof. Roman Danielewicz (Poltransplant), Prof. Iwona Grabska-Liberek (Warsaw Eye Bank), Assistant Professor Jolanta Korsak (Military Institute of Medicine), PhD Izabela Uhrynowska-Tyszkiewicz (National Centre for Tissue and Cell Banking), PhD Ewa Wroblewska-Czajka (SPZOZ District Railway Hospital in Katowice), MA Grażyna Płaszczewska (Eye Bank SPSK 1 Lublin ), MA Małgorzata Nejman (Eye Tissue Bank, Saint Barbara Hospital in Sosnowiec), Michał Pokwicki (Zachodniopomorskie Eye Bank) Non-Public Medical Centre "FRK Homograft" Sp. z o.o. [Limited].

\section{REFERENCES}

1. www.poltransplant.org.pl/statystyka_2014.html.

2. www.poltransplant.pl/Download/biuletyn2015 www.pdf.

3. Paplińska M. Osoby niewidome i słabo wiedzące. Konsekwencje wynikające z braku wzroku. http://www.adaptacje.uw.edu.pl/ /publikacje/edukacja/3_os_niewidome_i_slabowidz.html (accessed 20.06.2015).

4. Górecki A, Romaniuk A. Immunologia transplantacyjna. In: Jakóbisiak M, Stokłosa T, Lasek W, Gołąb J (eds.). Immunologia. PWN, Warszawa 1996: 621-622.

5. Kański J, Bowling B. Okulistyka kliniczna. Szaflik J, Izdebska J (eds.). Edra Urban\&Partner, Wroctaw 2013: 240-242.

6. Rozporządzenia Ministra Zdrowiaz dnia 9 października 2008 r. w sprawie wymagań, jakie powinien spełniać system zapewnienia jakości w bankach tkanek i komórek. (Dz. U. Nr. 190 poz. 1169).

7. Ustawa z dnia 1 lipca 2005 r. o pobieraniu, przechowywaniu i przeszczepianiu komórek, tkanek i narządów. (t.j. Dz. U. 2015 poz. 793).

8. Obwieszczenie Ministra Zdrowia z dnia 16 czerwca 2015 r. w sprawie ogłoszenia jednolitego tekstu rozporządzenia Ministra Zdrowia w sprawie wymagań, jakie powinien spełniać system zapewnienia jakości w bankach tkanek i komórek. (Dz. U. poz. 967).

9. Dyrektywa 2004/23/WE Parlamentu Europejskiego i Rady z dnia 31 marca 2004 r. w sprawie ustalenia norm jakości i bezpiecznego oddawania, pobierania, testowania, przetwarzania, konserwowania, przechowywania i dystrybucji tkanek i komórek ludzkich. http://orka. sejm.gov.pl/Drektywy.nsf/all/32004L0023/\$File/32004L0023.pdf.

10. Dyrektywa Komisji 2006/17/WE z dnia 8 lutego 2006 r. wprowadzająca w życie dyrektywę 2004/23/WE Parlamentu Europejskiego i Rady w odniesieniu do niektórych wymagań technicznych dotyczących dawstwa, pobierania i badania tkanek i komórek ludzkich.

11. Rozporządzenie Ministra Zdrowia z dnia 1 grudnia 2006 r. w sprawie sposobu prowadzenia centralnego rejestru sprzeciwów oraz sposobu ustalania istnienia wpisu w tym rejestrze. (Dz. U. Nr 228, z 2006, poz. 1671).

12. Ustawa o zawodach lekarza i lekarza dentysty. (t.j. Dz. U. 2015, poz. 464).

13. Ustawa o ochronie danych osobowych. (Dz. U. 2014, poz. 1182).

14. Ustawa z dnia 6 listopada 2008 r. o prawach pacjenta i Rzeczniku Praw Pacjenta. (Dz. U. 2012, poz. 159).

15. Rozporządzenie Ministra Zdrowia z dnia 4 grudnia 2009 roku w sprawie szczegółowych warunków pobierania, przechowywania i przeszczepiania komórek, tkanek i narządów. (Dz. U. Nr 213 2009, poz. 1656). 
16. Zarządzenie Ministra Zdrowia z dnia 25 marca 2014 r. w sprawie powotania Zespołu Roboczego ds. koordynacji funkcjonowania i rozwoju standardu ISBT 128. http://dziennikmz.mz.gov.pl/DUM_MZ/2014/47/ oryginal/akt.pdf (accessed 10.05.2015).

17. www.poltransplant.org.pl/alokacja2.html\# rogowka2015 \.

18. www.kcbtik.pl/zestawienia/bt2009.pdf.

19. www.poltransplant.org.pl/statystyka_2015.html15.
20. Stanowisko Rady Przejrzystości nr 54/2013 z dnia 25 marca 2013 r. w sprawie zakwalifikowania świadczenia opieki zdrowotnej "Protezowanie rogówki" jako świadczenia gwarantowanego http://www.aotm.gov.pl/www/assets/files/rada/rekomendacje_stanowiska/2013-SRP/R-03-2013-Protezowanie_rogowki/U_8_118_130325_stanowisko_54_protezowanie_rōgowki.pdf (accessed $20.03 .20 \overline{15}$ ). 